Article

\title{
Linking Sustainable Development Goals with Thermal Comfort and Lighting Conditions in Educational Environments
}

\author{
Isabel Montiel ${ }^{1,2,3, *}$, Asunción M. Mayoral ${ }^{3}{ }^{(}$, José Navarro Pedreño ${ }^{4} \mathbb{C}$, Silvia Maiques ${ }^{5}$ and \\ Gema Marco Dos Santos 4 \\ 1 Department of Statistics, Mathematics and Informatics, Universidad Miguel Hernández, 03202 Elche, Spain \\ Conselleria de Educació, Generalitat Valenciana, 03007 Alicante, Spain \\ 3 University Institute of Research CIO, Universidad Miguel Hernández, 03202 Elche, Spain; \\ asun.mayoral@umh.es \\ 4 Department of Agrochemistry and Environment, Universidad Miguel Hernández, 03202 Elche, Spain; \\ jonavar@umh.es (J.N.P.); gema.marcodos.santos@gmail.com (G.M.D.S.) \\ 5 Technical Department at CIEGSA (Educational Building and Infraestructures), Generalitat Valenciana, \\ 46018 Valencia, Spain; silviamaiquessamarra@gmail.com \\ * Correspondence: imontiel@umh.es; Tel.: +34-689-016-205
}

Received: 10 February 2020; Accepted: 5 March 2020; Published: 9 March 2020

\begin{abstract}
The present paper deals with a wide range of issues related to the environmental quality in learning spaces, such as thermal and visual comfort, as well as energy efficiency. All of these issues fall under the umbrella of the UN Agenda 2030 and Sustainable Development Goals (SDGs). Upon reviewing publications of past studies, interviews were conducted and questionnaires were distributed in public high schools in the province of Alicante, located in the Southeast of Spain. Sixteen high schools were selected for the interviews. Fifteen in the city of Elche, which is the total amount of the high schools in the city. One additional high school that was considered important for this research was included in the study due to the characteristics of the building design, excessively exposed to weather conditions. Significant differences were observed between schools built before 2000 and those built after that date. The latter, surprisingly, not more thermally and visually comfortable or energy efficient. The knowledge gained from our investigation will be of great benefit for architects, designers, engineers, school planners and principals in order to establish stronger connections between infrastructures and SDGs. A chart linking recommendations with specific SDGs is also included in this study.
\end{abstract}

Keywords: thermal comfort; energy efficiency; participatory design; school architecture; SDGs

\section{Introduction}

The design of educational spaces should go hand in hand with teaching and learning processes, as well as ensure comfortable conditions for the users of the building, as stated in learning space design guides, such as the one edited in 2015 by the Ministry of Education of Perú [1]. Ideally, schools should also be an example of sustainable design practices, especially now, in the midst of the climate emergency and of reaching the goals of Agenda 2030.

Before moving forward to consider the space and the conditions that foster learning, we deem it necessary to delimit the term "sustainable," which is a relatively recent term, nowadays extensively used. In fact, in Spain, the Diccionario de la RAE (Dictionary of the Spanish Royal Academy) [2], did not include the term "sustainable" as an entry until its $23^{\text {rd }}$ Edition, in October 2014, and defines it as follows: " 2 . Adj. used especially in ecology and economy in regard to what can withstand a long 
period of time without depleting resources or causing irreparable harm to the environment". Nearly thirty years before, in 1987, the concept of sustainable development was used for the first time in the Brundtland Report titled Our Common Future [3]: "Humanity has the ability to make development sustainable to ensure that it meets the needs of the present without compromising the ability of future generations to meet their own needs. The concept of sustainable development does imply limits ... "Spain, is currently working under the international Agenda 2030 passed by the United Nations in September of 2015, which defines 17 SDGs to meet during 2016-2030.

Having mentioned the history of the term "sustainable", it is now possible to present information that goes beyond the definition. In the education community and society in general, there is a general consensus, that we should teach our youth to work towards the three dimensions of sustainability, which are changing attitudes and behaviors, promoting a lifestyle that guarantees a balance between economic growth and social well-being, while being respectful with the environment, without compromising its resources [4,5]. Great efforts are being made to introduce sustainability in the curriculum and educational programs of all levels. Many activities, teacher-centered or student-centered, claim that sustainability is achieved where economic goals, social responsibility and environmental protection cross paths. However, the design of the school and learning spaces very often contradicts that theory and creates a gap between what seems good and well on paper and the reality in many education buildings found in our study report. We are well aware of the fact that the teaching-learning processes are complex and that multiple factors are involved [6]. Nonetheless, in 2019, sustainable development education is key for future citizens. Focusing on sustainable development generates benefit to any educational program.

Teenagers spend many hours of their day in educational buildings. Friends, teachers and the building all have a profound impact on their human and academic development. Studies conducted from a neuroscience perspective claim that the school premises have a "hidden" curriculum and that buildings educate [7]. Moreover, the design of the building has an impact on the maintenance costs [8] and, most importantly, it affects the health and well-being of the users [9].

It is true that there is increasing concern about learning spaces of all types and how they interact with emerging pedagogies and that this mainstream does not leave aside the design of the building itself. Thereby, literature is found both in the field of education $[7,10]$ and in the field of school architecture [11,12].

The field work carried out for this study in sixteen high schools, Institutos de Educación Secundaria (IES), in the province of Alicante enables us to provide a series of conceptual contributions and practical implications that can facilitate the link between infrastructures and SDGs in learning environments. Furthermore, this study moves us towards indicators included in the goals of the following objectives outlined in the 2030 Agenda:

SDG 3. Good health and wellbeing.

SDG 4. Quality Education.

SDG 7: Affordable and clean energy.

SDG 9: Industry, innovation and infrastructure.

SDG 11: Sustainable cities and communities.

SDG 12: Responsible consumption and production.

SDG 13: Climate action.

A chart linking these SDGs with our recommendations for enabling more sustainable educational spaces is included for reference in Section 3.

\section{Materials and Methods}

This article is part of a broader investigation that explores the hypothesis that learning spaces have an influence on health, on performance of students and teachers and on the maintenance costs of the buildings. The research team of this study is multidisciplinary, composed by educators, 
environmentalists, geographers and an architect, which makes discussion enlightening and gives a holistic approach to the investigation.

The information gathered is based on the quantitative data collected through a questionnaire about learning spaces and teachers' methodologies. Furthermore, we are concerned about the human feelings and emotions inside the learning spaces and therefore use a qualitative triangulation method that includes document analysis, site observations and face-to-face interviews. Moreover, as research progresses we are experiencing a move on to a research action method as we are not only achieving a greater knowledge of the situation but inducing change in schools visited.

The data collected through these methods seeks to answer the following questions:

1. Regarding thermal and visual comfort, can the design of learning spaces provide better health and well-being for the users?

2. Can the space design reduce maintenance costs in school buildings?

3. Are the recommendations published in national and international school design guides being implemented in the new constructions, or is there a gap between the suggestions and the built environment? And how big is the gap if proved?

The data that was gathered to prove the assumptions and answer the questions is based on several resources:

- Survey. A questionnaire composed of items related not only to space design, but also to emerging pedagogies, was distributed to the public high schools of the province of Alicante in July 2018.

The questions relative to thermal conditions were based on value judgments:

Referring to the classrooms you usually teach in ...

* (v107) They are naturally ventilated and ventilation is operational.

* (v108) They have efficient air conditioning that provides comfortable temperature throughout the school year.

Possible responses were:

* Yes, in all classrooms I teach in (codified with 2)

* Only in some classrooms I teach in (codified with 1)

* No, in none of the classrooms I teach in (codified with 0 ).

Thermal comfort is resumed through a new categorized variable, obtained from the sum of v107 and v108. High values of these sums ( 3 or 4 ) identify good thermal comfort in most classrooms; low values $(0,1,2)$ identify thermal deficiencies in most classrooms.

To discover if the schools built in Elche after year 2000 provide higher thermal comfort in classrooms the Chi-Squared test was used for the 109 sample responses obtained (56 teacher responses from schools built before 2000 and 53 after that date). The test was resolved at $95 \%$ confidence level.

- Review of geographical-climatic facts of the city of Elche.

- Site observations. Sixteen schools were chosen for this article. Fifteen in the city of Elche, which is the total number of public high schools in the city. One additional school was included in the study, considered unique and important for this research due to the special characteristics of the design of the building, and to it being exposed to excessive weather conditions. We will refer to this type of design, where the only indoor spaces are the classrooms and offices, as an "open-air building". All traffic and connecting areas are outdoors. An extreme example of this type of design is found at IES Mediterrània in Benidorm, located $60 \mathrm{~km}$ north of Elche. Figure 1 shows a connecting area between classrooms.

- Interviews. All the principals of the targeted schools were interviewed with a face-to-face interview with previously prepared questions that were modified as needed and new ones added according 
to the responses. Detailed notes and photographs were taken during the visits to the schools. All photographs in this paper were taken by the authors during the field trips. Visits to the high schools took place from July 2018 to May 2019, in different seasons of the year. The interviews with principals gave information about global conditions, as well as about ongoing sustainability educational projects.

- Review of scientific papers. The keywords used for the scientific research were: Thermal comfort in schools, Indoor Environmental Quality (IEQ), school design, SDGs.

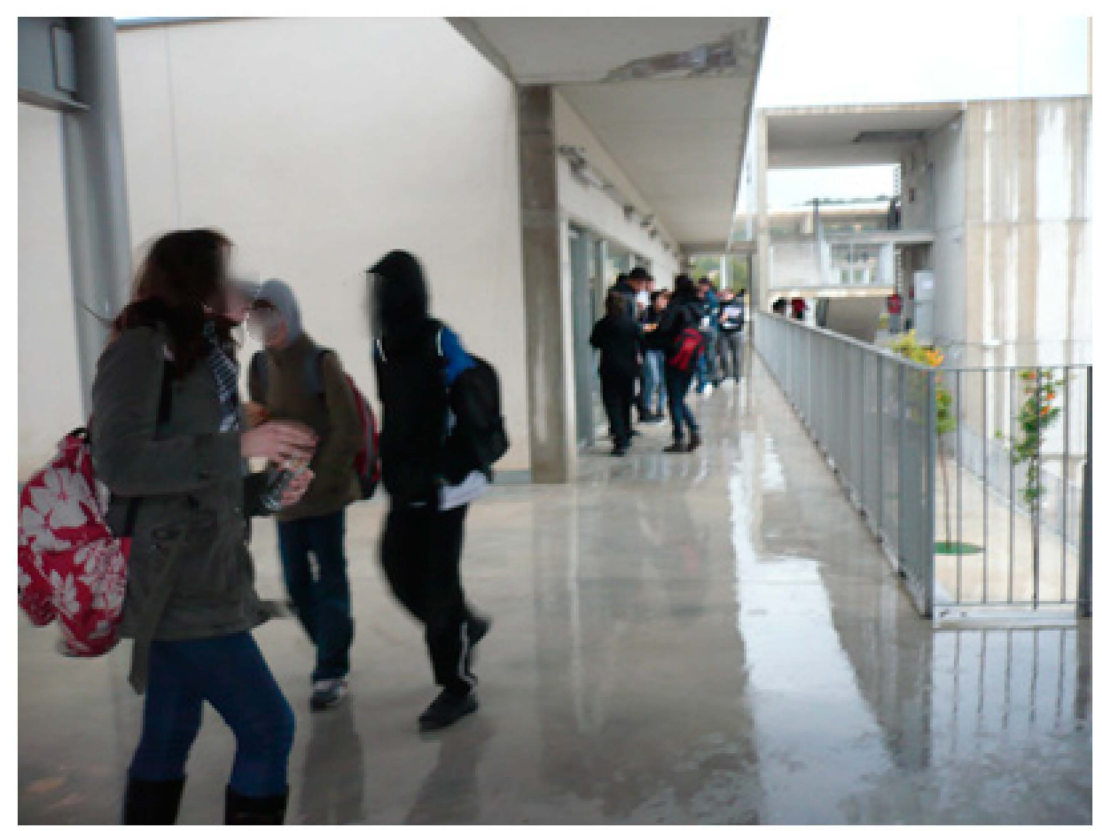

Figure 1. Hallway at an "open-air" school building.

\section{Results and Discussion}

In this section, the results of the study are presented and discussed further. Once the main causes that affect thermal and visual comfort in classrooms were identified from the literature, we cross-checked the information with the reality of the studied schools. The climate conditions of the zone and how the design of the building increases or palliates the effect of these weather conditions is discussed. We present some cases of open-air designs which affect not only thermal comfort but also health of users. Finally, considerations are made about the impact window design and add-ons such as shutters, blinds or blades have on thermal and visual comfort in the classrooms.

\subsection{Results of the Survey Regarding Thermal Comfort}

Figure 2 shows that in school buildings constructed after year 2000, that is new, modern design buildings, users feel more discomfort, $58.5 \%$ against $37.5 \%$. The p-value for the Chi-squared test is 0.045 , so a statistical relationship is proved from the available sample, relating higher thermal comfort to old school buildings, according to teachers' perception. 


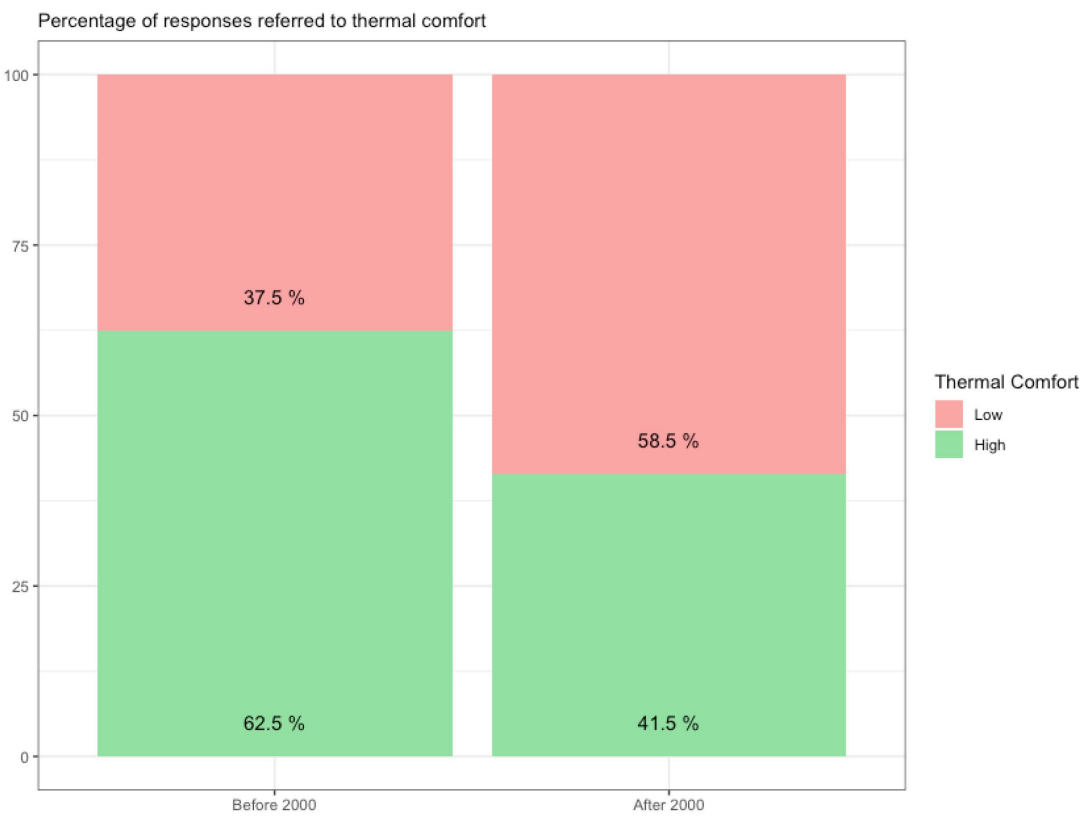

Figure 2. Graph shows that modern high school buildings in Elche are not more thermally comfortable.

\subsection{Discussion on Thermal and Visual Comfort for Learning}

Thermal comfort stands out as the most significant indicator amongst the items of environmental quality. It includes temperature, humidity and ventilation. However, in simple terms, we will refer to thermal comfort as the lack of discomfort regarding the temperature of a room [1]. Occupants highlight the importance of a pleasant temperature in order to feel comfortable [13,14]. This fact is confirmed by the teachers and principals of the studied schools.

Most of the papers reviewed focus on how to avoid or reduce an excess of heat in classrooms, both for performance and health reasons. Thus, guides in school design emphasize strategies such as cross ventilation, the use of vegetation near façades and the need to renew indoor air at least every hour, not only to cool the room but also in order to avoid somnolence due to lack of oxygen or viral epidemics $[1,15]$. Air renewal is also necessary to avoid toxic particle accumulation. A study of the air quality of schools in the coastal area of the southeast of Spain confirms that indoor air quality depends more on the design characteristics and ventilation of the space than on the location of the school in a rural, urban or industrial area [16]. Symptoms of weariness, fatigue and headaches have been reported in environments with poor ventilation [14,17]. Concerning performance, there is evidence that concentration levels are affected by the thermal conditions of offices and learning spaces [18]. In the case of young students, the ability to concentrate can be reduced as far as $30 \%$ and also motivation to perform well diminishes [19]. Data collected from schools in countries as far apart as Argentina [20] and Finland [21], confirm that academic results improve in environments with comfortable climatic conditions. It is considered that temperatures between 21 and $22{ }^{\circ} \mathrm{C}$ are ideal for a classroom environment [14]. It must also be taken into account that comfortable thermal conditions also depend on personal characteristics of the users such as age, gender, weight, clothes, activity, etc. [20], not only on physical indicators of the space. Nevertheless, the design of the building has a pivotal role in environmental comfort.

Visual quality and lighting are also related to the health of the occupants and to saving energy in the building [22] and are closely associated with window design. In the assessment of visual comfort, the following factors are taken into consideration: the amount of natural light, the uniformity of light, the quality of light in rendering colors, and the risk of glare [23]. As was the case in thermal comfort, visual comfort can be perceived in different ways according to age and the type of activity taking place in the room [13]. In all the schools visited we observed that artificial light is used in learning spaces 
regardless of the size of the windows or the amount of natural light entering the room, this is so, even in the school cafeterias. It was noted that the lights are only switched off when using projectors and digital whiteboards.

\subsection{Climatic Conditions of the Province of Alicante and City of Elche}

Alicante is the southernmost of the three provinces that form the Valencian Community, situated in the southeast of Spain as seen in Figure 3. The climate is characterized as Mediterranean [24]. Table 1 shows climatic data for the city of Elche, with an average annual temperature of $17.8^{\circ} \mathrm{C}$ and an average annual rainfall of $318 \mathrm{~mm}$ [25].

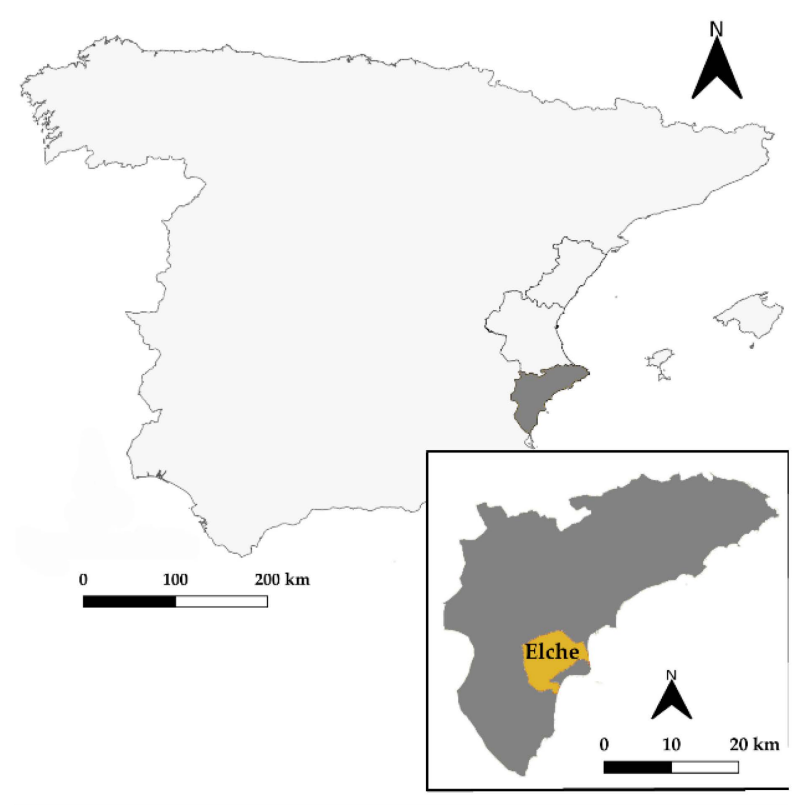

Figure 3. Location of the Valencian Community, the province of Alicante and city of Elche.

Table 1. Historical climatic data in Elche [25].

\begin{tabular}{ccccccccccccc}
\hline & Jan & Feb & Mar & Apr & May & Jun & Jul & Aug & Sep & Oct & Nov & Dec \\
\hline Mean Temp $\left({ }^{\circ} \mathrm{C}\right)$ & 10.5 & 11.5 & 13,6 & 15.8 & 18.9 & 22.9 & 25.6 & 26 & 23.4 & 19 & 15 & 11.9 \\
\hline Min Temp $\left({ }^{\circ} \mathrm{C}\right)$ & 5.4 & 6.1 & 8 & 10.4 & 13.3 & 17.1 & 19.6 & 20.1 & 17.7 & 13.7 & 9.8 & 7 \\
\hline Max Temp $\left({ }^{\circ} \mathrm{C}\right)$ & 15.6 & 16.9 & 19.3 & 21.3 & 24.5 & 28.7 & 31.6 & 31.9 & 29.2 & 24.4 & 20.2 & 16.8 \\
\hline Precip $(\mathrm{mm})$ & 20 & 22 & 22 & 33 & 28 & 17 & 4 & 9 & 35 & 60 & 38 & 30 \\
\hline
\end{tabular}

As it can be seen in Table 1, the months of June, July, August and September register high temperatures (maximum rates above $25{ }^{\circ} \mathrm{C}$ ). According to the Royal Decree 485/1997 [26], the National Institute of Safety and Hygiene suggests, for offices, a temperature range between $17^{\circ} \mathrm{C}$ and $27^{\circ} \mathrm{C}$. In learning spaces, an average temperature of $22^{\circ} \mathrm{C}$ is considered pleasant for most of the users and above $25^{\circ} \mathrm{C}$ students claim to feel discomfort [14].

November to March and even April, months in which educational buildings are fully occupied, show average temperatures between $10{ }^{\circ} \mathrm{C}$ and $15{ }^{\circ} \mathrm{C}$ and maximum ones below $21^{\circ} \mathrm{C}$; these temperatures, combined with the fact that the relative humidity is around -even above- $50 \%$ throughout all the year, makes it necessary to use central heating for thermal comfort. In the months of May and October, with average temperatures between $15^{\circ} \mathrm{C}$ and $20^{\circ} \mathrm{C}$ (and maximum rates below $25^{\circ}$ ) rooms with natural ventilation would be more energy efficient. In June, July and September working conditions in offices and classrooms are thermally very uncomfortable without air conditioning. Most of the classrooms of the schools visited do not have air conditioning. Some of them have ceiling fans. 
According to the school calendar for the year 19/20 [27], classes in high schools began on 9th September and will finish on 16th June. July is used for extra-ordinary exams and lesson planning. The high temperatures reached during this month make spaces without air-conditioning very uncomfortable to work in.

Regarding rainfall, the area is very dry, though its proximity to the sea gives, as commented before, relative humidity indicators above $50 \%$ most of the year. Elche can be considered semi-arid with scarce precipitation, sometimes below $300 \mathrm{~mm}$ per year. Its most prominent feature is that rainy days happen mostly in autumn and spring and very often they are torrential rains which can cause flooding and sometimes classes have to be cancelled [28].

\subsection{Relevant Information and Discussion about the Studied Schools}

In 1990 the Organic Act on the General Organisation of the Education System (LOGSE) [29] was passed in Spain. This is an important fact, as it led to significant changes not only in curriculum and methodologies but also in the standards of school building design. The ratio of students per group was reduced from 40 to 30, which affected the size of the classroom in that the standards were cut down accordingly. As stated in the Royal Decree 132/2010, Title IV, article 14a [30], the size of the classroom should be calculated multiplying $1.5 \mathrm{~m}^{2}$ per student. The ratio for compulsory secondary education is 30:35, which gives a size for most rooms of $45 \mathrm{~m}^{2}$ in new schools. With the LOGSE/1990, another important change takes place: vocational studies and high school studies are integrated in the same buildings and the differentiation between Instituto Nacional de Bachillerato and Instituto de Formación Profesional disappears. All high schools are, since then, called Institutos de Educación Secundaria (IES) and must be adapted to the requirements of both vocational studies and compulsory studies, having to deal with the consequences this implied for changing classrooms and workshops.

The construction of a new high school in Elche should start in 2020, after a long wait as echoed by local media [31]. The conclusions of this paper could benefit greatly the forthcoming new building and help avoid repeating past mistakes encountered in the study targeted school buildings. One would tend to believe that a new school building would have all the sustainable parameters required for the twenty first century; however, reality sometimes proves to be the opposite. This is the case of IES Mediterrània in Benidorm, described as very uncomfortable for the occupants regarding Indoor Environmental Quality (IEQ), not only in terms of thermal and visual but also acoustics [32]. Of the principals interviewed, $100 \%$ argue that these situations occur due to lack of participatory design.

In Table 2 the schools studied are shown with available and relevant information for our study.

The student populations of the schools in our study register 14,507 students, and 1485 teachers work on their premises. Six of the studied schools were designed after year 2000 with an approximate average investment of 12 million euros per school. According to the interviews carried out for this study many of the inconveniences of environmental comfort and drawbacks for sustainable development are not a matter of lack of financial investment. Around 13 million euros are expected to be invested in the construction of the new IES $\mathrm{N}^{\circ} 11$ in Elche [31].

Figure 4 shows the location and floor plan of the high schools within the city of Elche. Depending on the direction in which the classrooms are oriented, they will have different thermal conditions.

All schools use fossil fuels for heating systems. Principals are aware of the importance of thermal comfort on their premises, as can be inferred from the remark by Principal A: "I cut down on other expenses but never on gasoil for heating the school." None of the buildings have functional sectorial heating. This implies, for example, that classrooms facing S, E or W, are overheated compared to those facing $\mathrm{N}$ and to avoid discomfort users of $\mathrm{S}$ rooms open the windows, with a consequent waste of energy during the coldest months; in the hottest months, the situation is reversed, as temperatures above $28^{\circ} \mathrm{C}$ are not unusual. Some of the schools visited have received donations from the parents' association in order to install ceiling fans in the warmest classrooms. 
Table 2. Relevant information of targeted schools (The legend for the columns is: (1) Name of the high school (IES). (2) Year of construction. (3) Geographic orientation of classrooms. (4) Heating system: Fuel (F) or Gas (G). (5) Operational sectorial heating system: Yes/No. (6) Are classroom windows complemented with awnings? yes/no/some. (7) Type of window: Sliding $(\mathrm{S})$ or Hinges $(\mathrm{H})$. (8) Size of windows: Regular (R) or Oversize (O). (9) Type of shading devices: Shutters (S), Venetian blinds (V), Rolling blinds (R), Blades (B). (10) Number of students. (11) Number of teachers).

\begin{tabular}{|c|c|c|c|c|c|c|c|c|c|c|}
\hline (1) & (2) & (3) & (4) & (5) & (6) & (7) & (8) & (9) & (10) & (11) \\
\hline 1.La Asunción & $1963 / 1968$ & $\mathrm{~N}, \mathrm{~S}, \mathrm{E}, \mathrm{W}$ & $\mathrm{F}$ & no & yes & Sliding & $\mathrm{R}$ & Shutters & 850 & 80 \\
\hline 2. Carrús & $1975 / 1995$ & $\mathrm{~N}, \mathrm{~S}, \mathrm{E}, \mathrm{W}$ & $\mathrm{F}$ & no & yes & $S$ & $\mathrm{R}$ & $S$ & 1200 & 129 \\
\hline 3. Sixto Marco & 1955 & $\mathrm{~N}, \mathrm{~S}, \mathrm{E}$ & $F$ & no & yes & $\mathrm{S}$ & $\mathrm{R}$ & $\mathrm{S}$ & 1200 & 131 \\
\hline 4. La Torreta & 1978 & $\mathrm{~N}, \mathrm{~S}$ & $\mathrm{~F}$ & no & no & $S$ & $\mathrm{R}$ & $\mathrm{S}$ & 1400 & 154 \\
\hline 5. Pedro Ibarra & 1979 & NE,SW & $\mathrm{F}$ & no & yes & $\mathrm{S}$ & $\mathrm{R}$ & $\mathrm{S}$ & 460 & 62 \\
\hline $\begin{array}{l}\text { 6. Montserrat } \\
\text { Roig }\end{array}$ & $1986 / 87$ & N,S,E,W & $\mathrm{F}$ & no & yes & S & $\mathrm{R}$ & S & 1000 & 100 \\
\hline 7. Tirant Lo Blanc & 1991 & $\mathrm{~N}, \mathrm{~S}, \mathrm{E}, \mathrm{W}$ & $\mathrm{F}$ & no & yes & $\mathrm{S}$ & $\mathrm{R}$ & $\mathrm{S}$ & 915 & 89 \\
\hline 8. Severo Ochoa & 1994 & NE,SW & $\mathrm{F}$ & no & yes & $\mathrm{S}$ & $\mathrm{R}$ & $\mathrm{S}$ & 900 & 88 \\
\hline $\begin{array}{l}\text { 9.Cayetano } \\
\text { Sempere }\end{array}$ & 1994 & $\mathrm{~N}, \mathrm{~S}, \mathrm{E}, \mathrm{W}$ & $\mathrm{F}$ & no & yes & S & $\mathrm{R}$ & S & 1100 & 103 \\
\hline 10. Victoria Kent & 1997 & $\mathrm{~N}, \mathrm{~S}$ & $\mathrm{~F}$ & no & yes & $\mathrm{S}$ & $\mathrm{R}$ & $\mathrm{S}$ & 1300 & 120 \\
\hline 11. Misteri & 2004 & $\mathrm{~N}, \mathrm{~S}$ & $\mathrm{~F}$ & no & no & $\mathrm{H}$ & $\mathrm{O}$ & venetian & 1200 & 112 \\
\hline 12. Nit de l'Albà & 2004 & $\mathrm{~N}, \mathrm{~S}, \mathrm{E}, \mathrm{W}$ & GAS & no & some & $\mathrm{H}$ & $\mathrm{O}$ & blades & 917 & 92 \\
\hline $\begin{array}{l}\text { 13.Joanot } \\
\text { Martorell }\end{array}$ & 2004 & NE,SW & F & no & no & $\mathrm{H}$ & $\mathrm{O}$ & blades & 765 & 80 \\
\hline 14. La Foia & 2004 & $\mathrm{~N}, \mathrm{~S}$ & $x$ & no & no & $\mathrm{H}$ & $\mathrm{R}$ & - & 500 & 65 \\
\hline 15. Torrellano & $2003 / 04$ & $\mathrm{~N}, \mathrm{~S}$ & $x$ & no & no & $\mathrm{S}$ & $\mathrm{O}$ & - & 800 & 80 \\
\hline 16. IES $\mathrm{N}^{\circ} 11$ & Future & & & & & & & & & \\
\hline $\begin{array}{l}\text { 17.IESMediterrània- } \\
\text { Benidorm }\end{array}$ & 2006 & E & $X$ & no & no & S & $\mathrm{O}$ & $\begin{array}{l}\text { Rolling } \\
\text { blinds }\end{array}$ & 910 & 112 \\
\hline
\end{tabular}

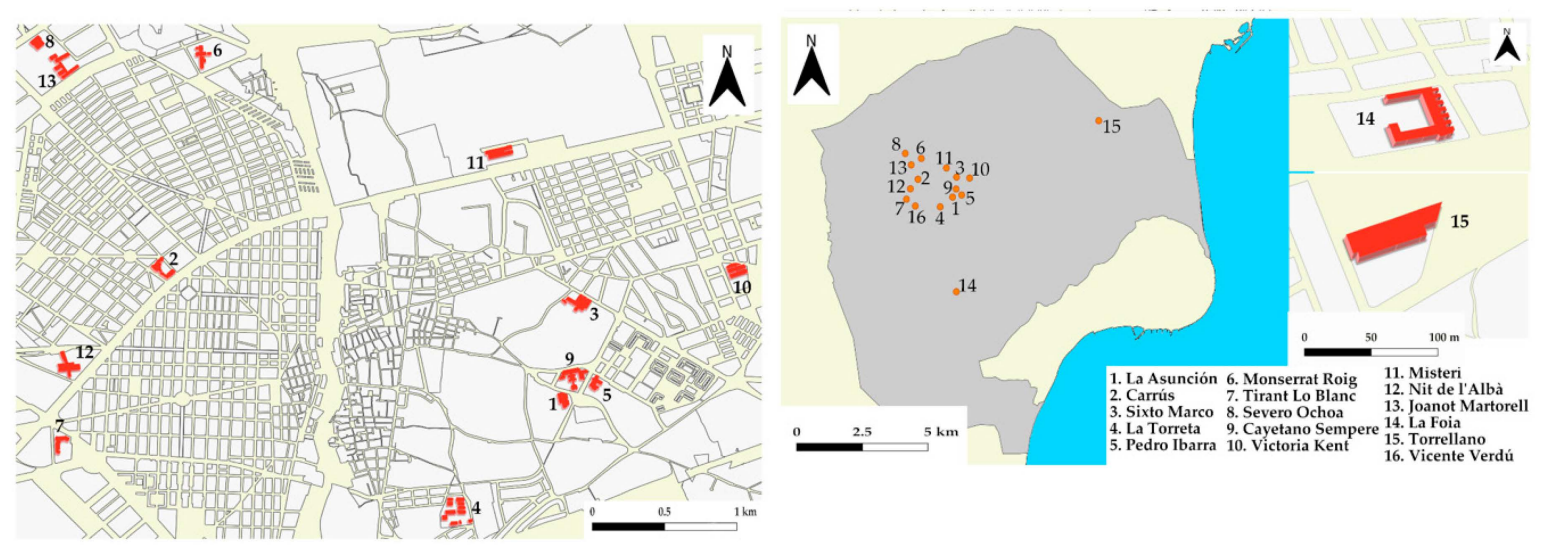

Figure 4. Location of the studied schools in Elche. (16. Vicente Verdú is the programmed future high school).

Another issue takes place in schools that have afternoon and evening shifts; during those shifts the occupancy of the building is not always 100\%; however, heating must be connected as if the building were fully occupied. What is important for our study regarding how to facilitate SDGs is that none of the targeted school buildings use renewable energies. Hopefully, Spanish regulations passed in 2019 [33] will encourage changes that will promote the use of energy from renewable sources. 


\subsection{The Importance of Window Design in Thermal Comfort}

The design of the windows, size, type of shades, shutters, etc., have an influence on the thermal comfort, as well as on the visual comfort and maintenance costs.

The premises of the schools targeted in this study were built between 1963 and 2006. While IES Sixto Marco started functioning as a Vocational College in 1955, very little remains of the first building constructed. During the field work, a great difference was noticed in the design of windows between schools built in the twentieth century, with traditional materials and standard sizes, and those constructed in the twenty first century. IES Misteri, Nit de L'Albà, Joanot Martorell, La Foia, Torrellano and Mediterrània, were built between 2004 and 2006, with a modern, trendy design.

The following figures illustrate the main issues that teachers, students and school administrators must deal with:

- "Oversize" windows. Most of the windows in these modern buildings are larger ("oversize") than what could be considered practical for a school, according to teachers' perception. This does not mean that they do not comply with the established regulations but the size and the add-ons they need for shading are a cause of complication for the users. Furthermore, to achieve a high energy rating and generate an optimal thermal and acoustic insulation it is convenient to control window size, as glass reduces acoustic and thermal comfort in the room. For a classroom that occupies a floor area of 50 square metres, the window area to the exterior should be equal or greater than $15 \%$ of the floor area, that is $7.5 \mathrm{~m} 2$ but never larger than $60 \%$ [34]. What principals argue is that even if the window area does not exceed that $60 \%$, a large design requires add-on elements that are more expensive to repair and more difficult to handle. In Figures 5 and 6, one can compare the difference between an "oversize" window and rolling blind (Figure 5) and a more accessible and comfortable design for the users (Figure 6).

- "Fish-tanks". Some of the modern buildings combine glass walls and concrete walls, giving rise to spaces referred to by the teachers as "fish-tanks", without natural ventilation, illustrated in Figures 7 and 8. These cubicles are planned as being used for cafeterias, meeting rooms, libraries, assembly rooms, gyms and sometimes toilets. The massive use of glass with little natural ventilation has several major setbacks. Stated by the principals of the high schools are the following: In first place an increase of temperature. Overheating makes "fish-tanks" uninhabitable without air conditioning, surprisingly, not only during the summer months. This adds an extra cost to the school budget and works against energy efficiency and thermal comfort. In second place, difficulties for cleaning are mentioned as an increase of expenses. In many cases vertical work companies need to be contracted to clean the windows, adding an extra cost to the maintenance. As a result, they report, some are never cleaned, which conveys a sense of abandonment and neglect. All toilets in traditional schools have natural ventilation (like in Figure 9) whilst in modern ones, many have been designed without natural light and ventilation (Figure 10). They consequently consume more energy for lighting and generate smell issues.

- Sliding windows vs hinged windows. In classrooms, sliding windows are more comfortable than hinged windows. Opening the latter becomes an obstacle as they interfere with desks and materials situated near the window. Moreover, when opened they reduce the amount of useful space in the room and block the view for the student as seen in Figure 11a,b. If they are oversized and with door dimensions, what we have called "walk out windows" extra control is needed to avoid adolescents walking out to the gallery. See Figures 12 and 13. 


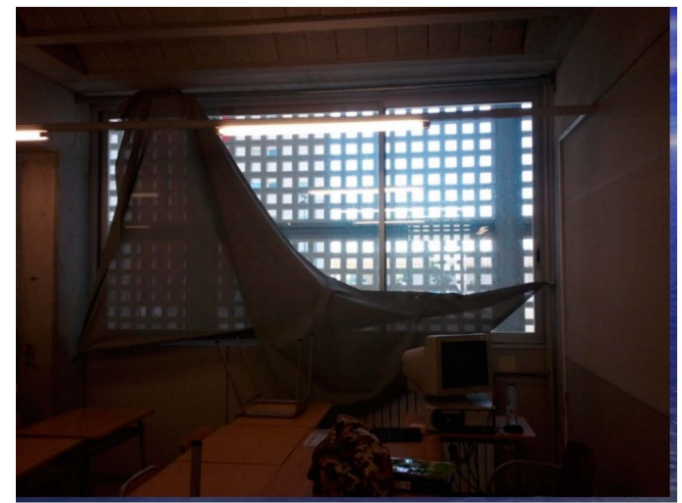

Figure 5. Oversize window and rolling blind, not easy to handle and more expensive for maintenance and repairs.

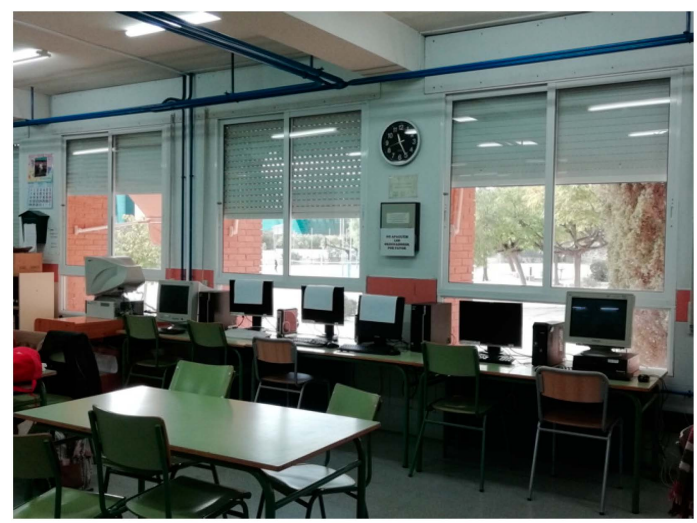

Figure 6. Standard, sliding windows and shutters for shading and darkening the room. More practical, less expensive and easier to find substitution elements in local businesses.

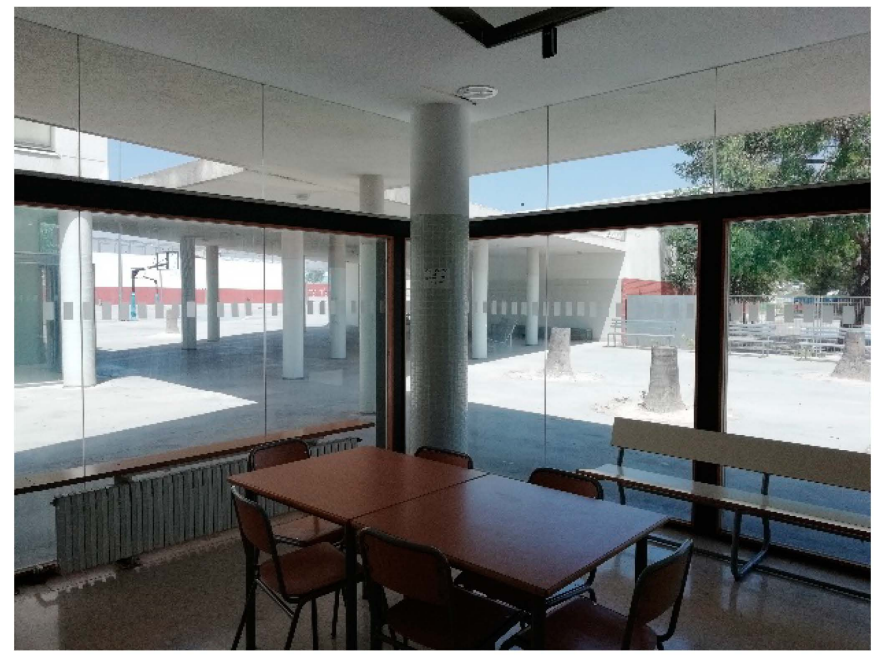

Figure 7. "Fish tank" cafeteria without natural ventilation in a modern school. 


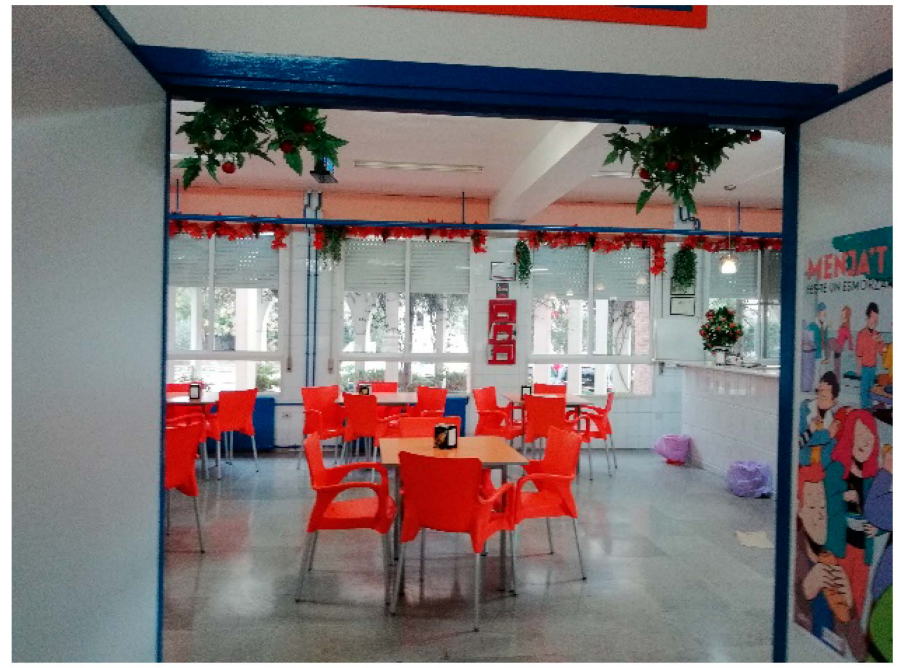

Figure 8. Traditional cafeteria with comfortable windows and shutters in an old school with cross ventilation.

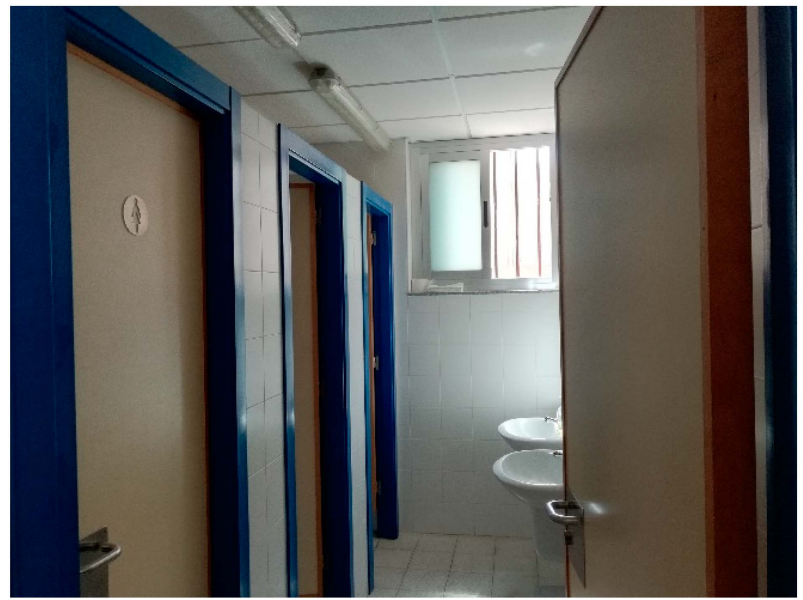

Figure 9. Toilet of a traditional school with natural light and ventilation.

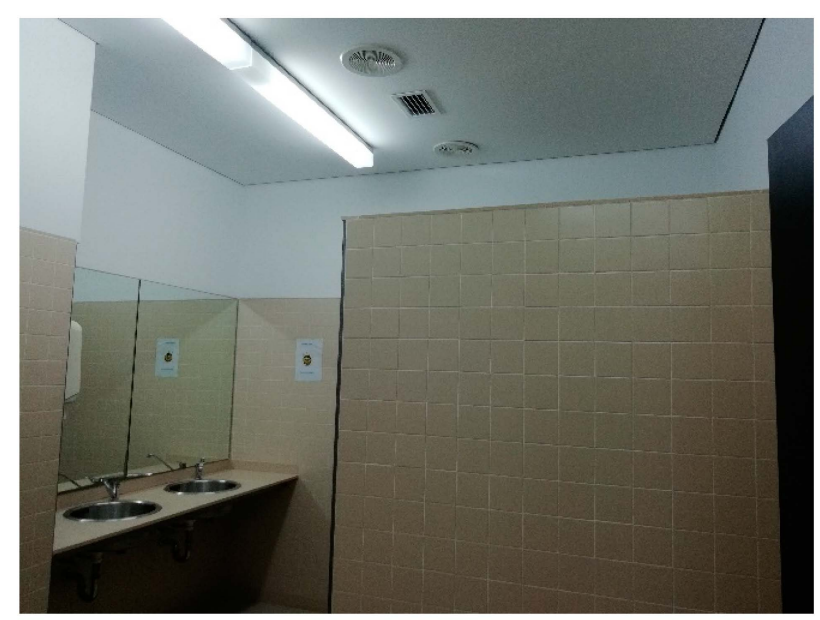

Figure 10. Toilet in a modern school, without natural ventilation. 


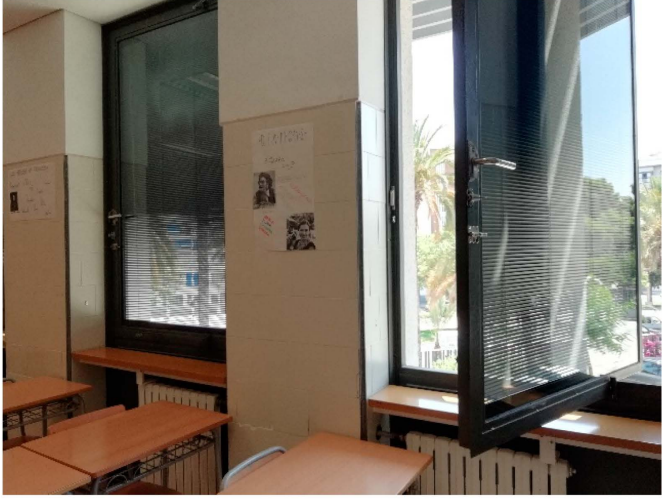

(a)

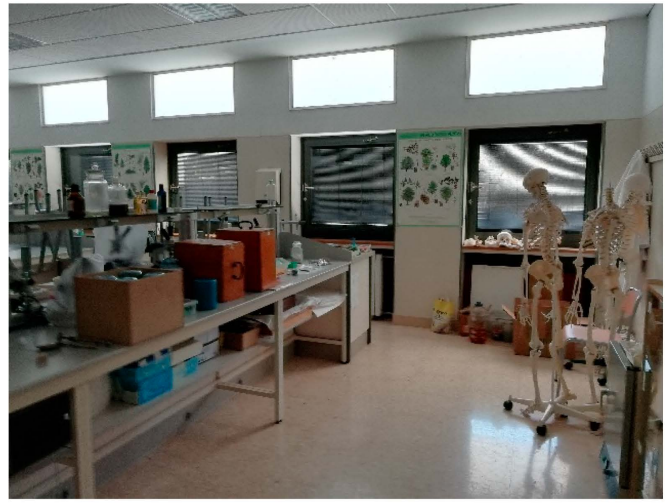

(b)

Figure 11. (a) Hinged window with a sophisticated system of venetian blinds incorporated in between the two glass sheets of the window are expensive to repair. (b) Hinged windows reduce the amount of useful space in the room. They are not functional.

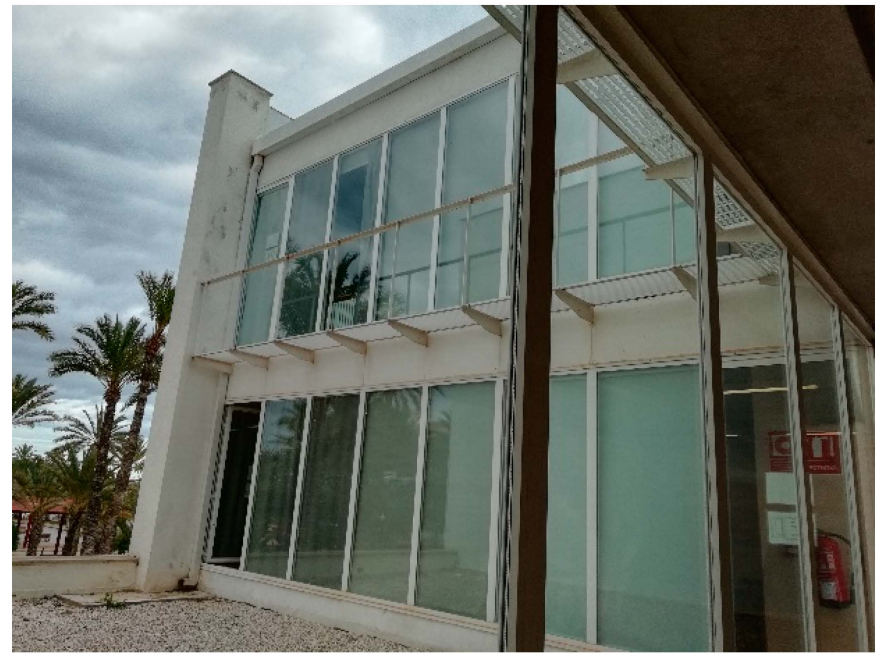

Figure 12. "Walk-out windows" seen from the outside.

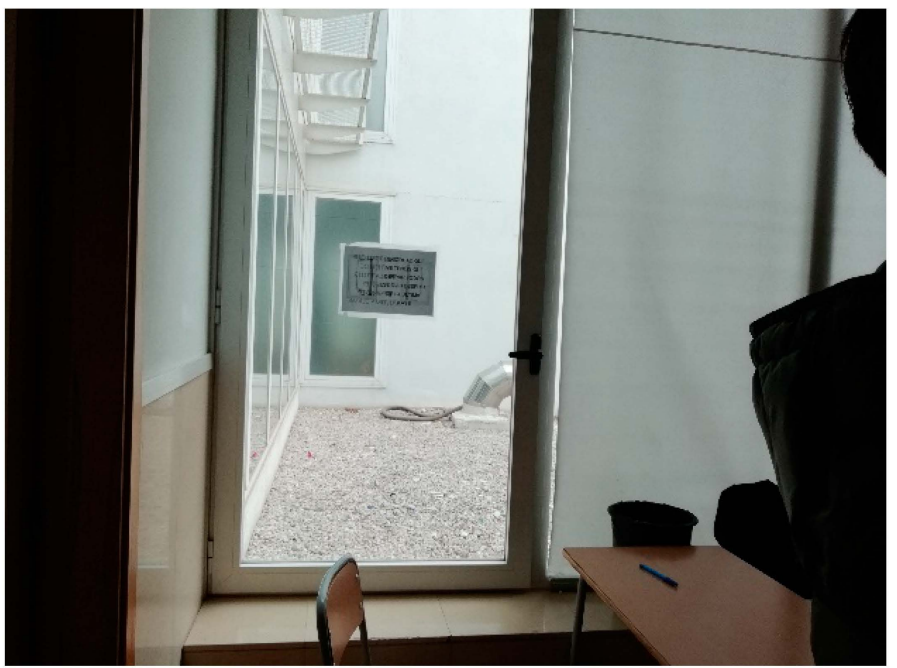

Figure 13. Hinged, "walk out" window seen from inside of the classroom. The difficulties of opening these windows lead to tolerating higher temperature in the rooms. 


\subsection{The Importance of Window Design in Visual Comfort}

Regarding visual comfort, the issues reported are mainly related to the need to darken the space and to avoid glare on screens and boards. Current practices and methodologies use digital devices, pc projecting beams and smartboards in the classroom, making it necessary to darken the room several times during a session for a correct visualization of text and images on the screens. As a result of this, several issues arise:

- Oversize windows and modern devices present more difficulties for darkening the rooms. In the visit to new school buildings, we spotted windows covered with dark papers, as a quick and temporary solution to reduce illuminance in the room and improve the visual quality of the presentations and videos that are being projected during the lessons. Principals report that shutters and awnings are more practical, and are repaired by local companies which makes maintenance quicker and cheaper (Figure 14) than repairing sophisticated roller blinds (Figure 5), venetian blinds (Figures 11 and 15) or modern shading blades (Figure 15).

- Glare is also an important issue in classrooms. While methodologies are changing and not all activities are centered on the teacher and blackboard, the truth is that in all the inspected schools, most classes were organized with desks facing the board. Chalkboards are still extensively used in Spanish public high schools. Teachers report that it would be of great help for their performance and for the visual health of the students to conduct an in depth study in regards to the best location for a board or a screen and also to consider the colors and materials to avoid glare issues. Rolling projection screens should not be placed covering the chalk or whiteboard when unrolled as these are needed for writing. In most rooms the projector has been fixed to the ceiling in the center, reflecting on a screen that covers the board when unrolled.

- Finally, blades and other shading devices that block a direct view of the exterior are not valued by the occupants as they convey the sensation of being in a jail (Figure 16). A view of nature and landscape is appreciated $[7,15]$ and in the balance of advantages it weighs more than the inconveniences caused by distractions that some may argue.

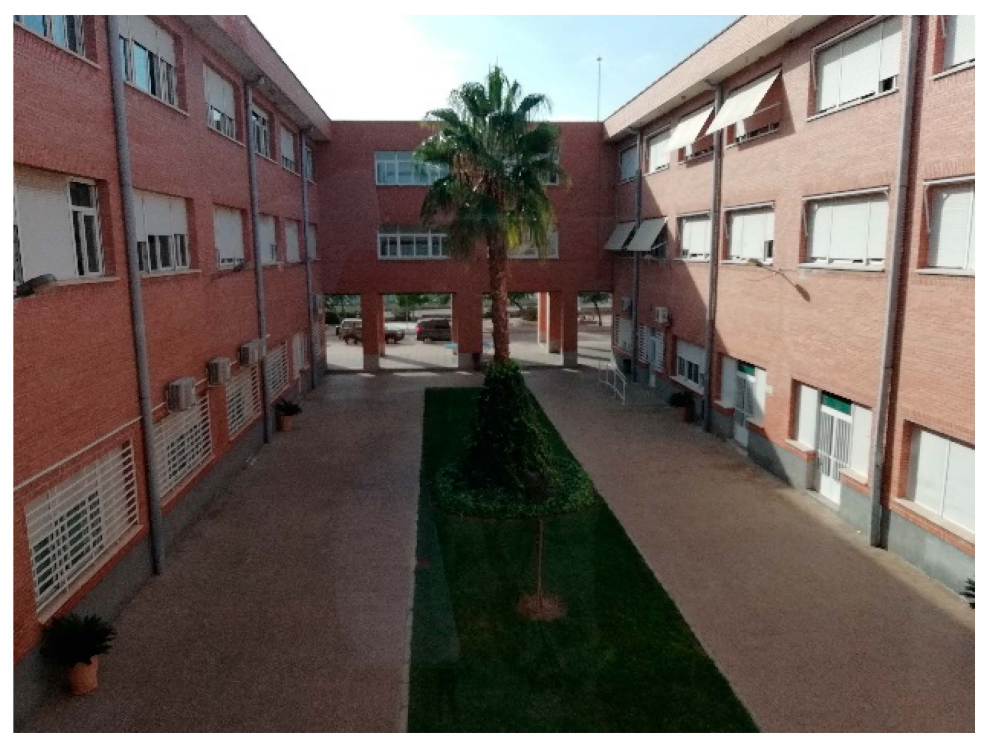

Figure 14. Awnings and shutters for south facing classrooms. 


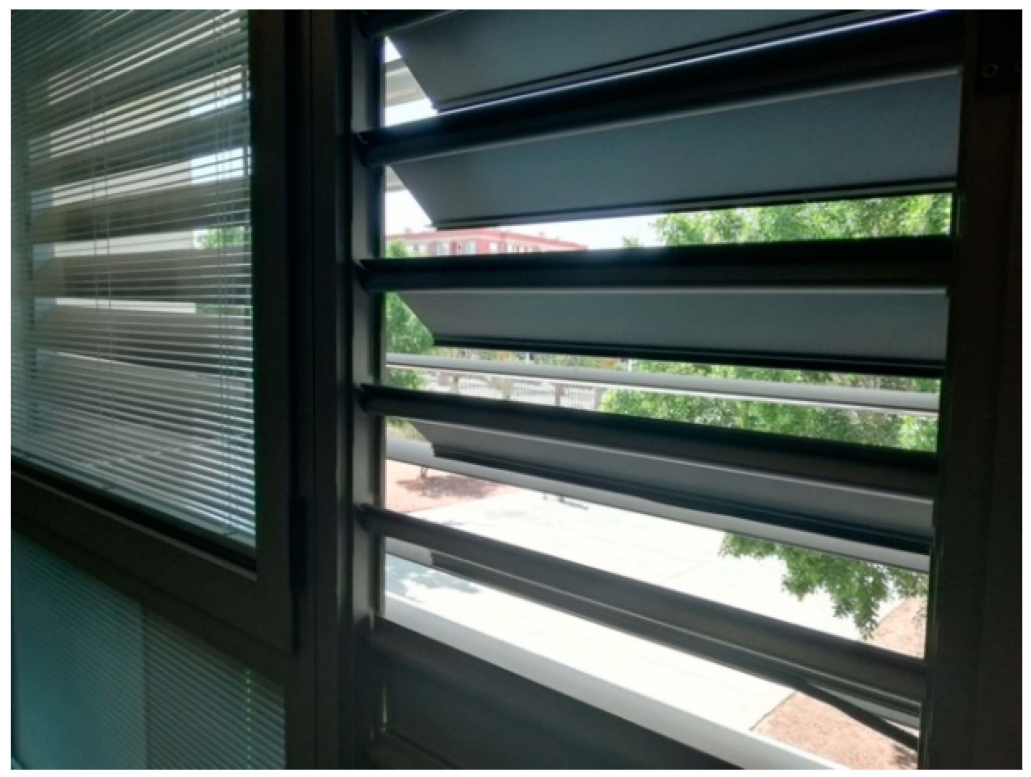

Figure 15. Fixed blades block the view of nature.

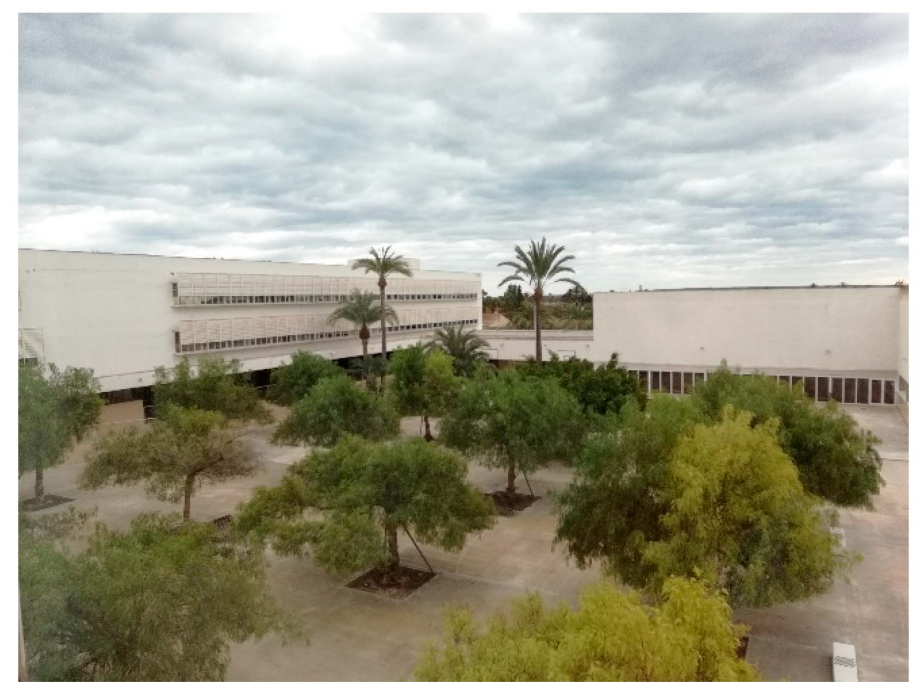

Figure 16. Fixed blades and trellis, as seen in many modern school buildings, may have an aesthetic function from the outside but are not visually comfortable for users from the inside (see Figures 5 and 15).

Principals report that this is not to say that they are against outstanding designs, but in order to build sustainable schools, architects and engineers should hold meaningful conversations with the users of the building. We find appropriate recommendations in all guides written for the design of school buildings, some as clear as those included in the Guide for the design of educational spaces published for the optimization of investment in school infrastructures in Chile in 1999 [15] (p.44): "The design of the educational institution should follow a construction system that complies simplicity. Priority requirements are: high durability materials, low cost, of easy maintenance and replacement. The use of unique materials, techniques or suppliers should be avoided in order to enable availability of supplies and proper repair work." In Valencian Community guides for the design of school buildings have been published since 1998, the last one in July 2019 [34]. However, they are recommendations and not always followed, as this research proves. 
3.7. Open-Air Building Design Increases Thermal Discomfort, Maintenance Costs and Has An Influence on Methodologies

- Thermal discomfort due to open-air design. Given the non-extreme climatic conditions of Elche and Benidorm, it may seem unnecessary to mention thermal discomfort due to cold, wind or rain. However, as result of the interviews and questionnaires conducted it is seen that some modern school designs do not protect users against drafts, rain, and abrupt temperature changes as they have an excessive open-air design. It seems necessary to insist on the fact that Institutos de Educación Secundaria (IES), register students for vocational studies, as well as compulsory levels and operate on different shifts and long opening hours. Seven of the studied schools open from $08 \mathrm{~h}$ to $22 \mathrm{~h}$. In open-air building design, thermal discomfort is more severe, especially during afternoon and evening shifts. It is also important to reveal that most sessions in high schools last 55 minutes. With few exceptions, users (students, teachers, families, concierges, cleaning staff, etc.) are required to move frequently around the premises and therefore, occupants appreciate a design that guarantees thermal comfort. This is linked with good health and well-being (SDG 3). Voice disorders and throat issues are common among teachers, $[35,36]$. When the rooms open directly to an outdoor area, occupants are required to put on coats every 55 minutes from November until March when they change classrooms or if they need to access other spaces (toilets, cafeteria, offices, etc.). In Alicante, although precipitations are scarce, they take place during school months, in autumn and spring, as shown in Table 1. An excessive outdoor design complicates mobility between classrooms and causes thermal discomfort, not only for teachers and students but also for parents when waiting to be attended, as is the case at IES Mediterrània in Benidorm.

- An open-air design school building restricts the amount of thermal comfortable learning space. Learning spaces are no longer only classrooms. When hallways and connecting areas are thermally comfortable they can be transformed and used for emerging pedagogies, more student centered (video and audio recordings, foreign language speaking in small groups, interviews, co-working, projects, etc.) as seen in Figures 17 and 18. Learning environments for new pedagogies foster an education where students can carry out activities autonomously [37]. Principals argue that the difficulties and expenses of transforming spaces in open air buildings are higher compared to those that are more traditional.

- Maintenance costs and added expenses for exhibiting students' work. Regarding the type of materials required for information boards and for exhibiting students' projects in open-air buildings, they are not standard and consequently they are more expensive and difficult to maintain. A supplementary effort is needed in creativity for exhibitions suitable for outdoor use. The possibilities of exhibiting students' work are much higher in spaces that are indoors. See the difference between an outdoor entrance hall (Figure 19) and an indoor one (Figure 20). This has an influence on teachers' motivation and methodologies according to the interviewees. 


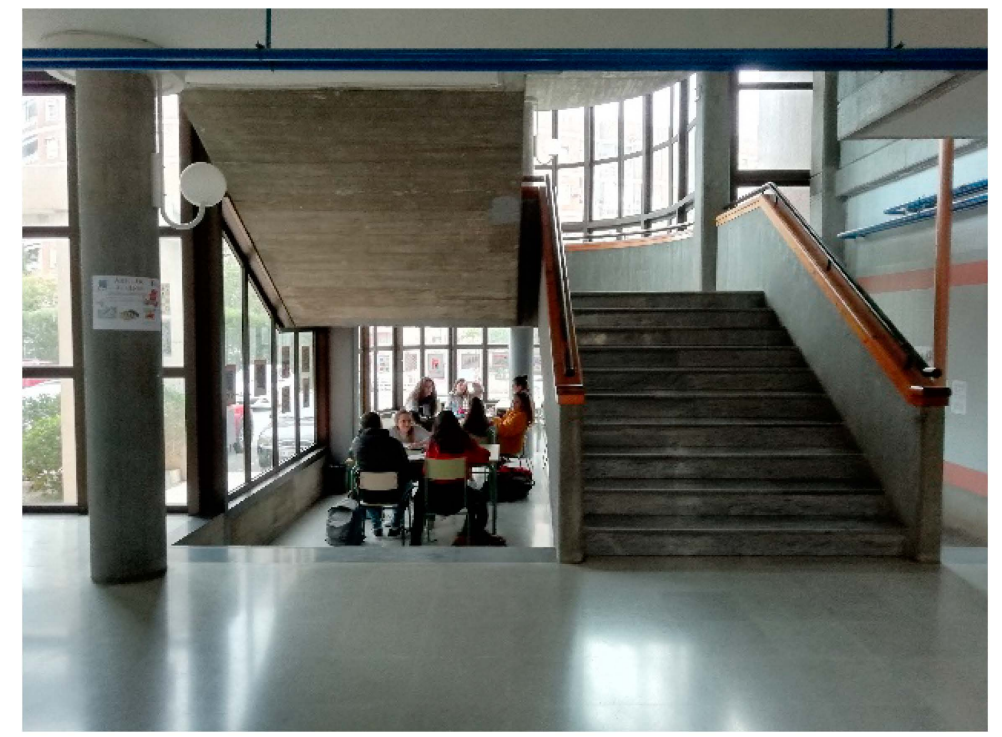

Figure 17. Co-working in an adapted indoor learning space.

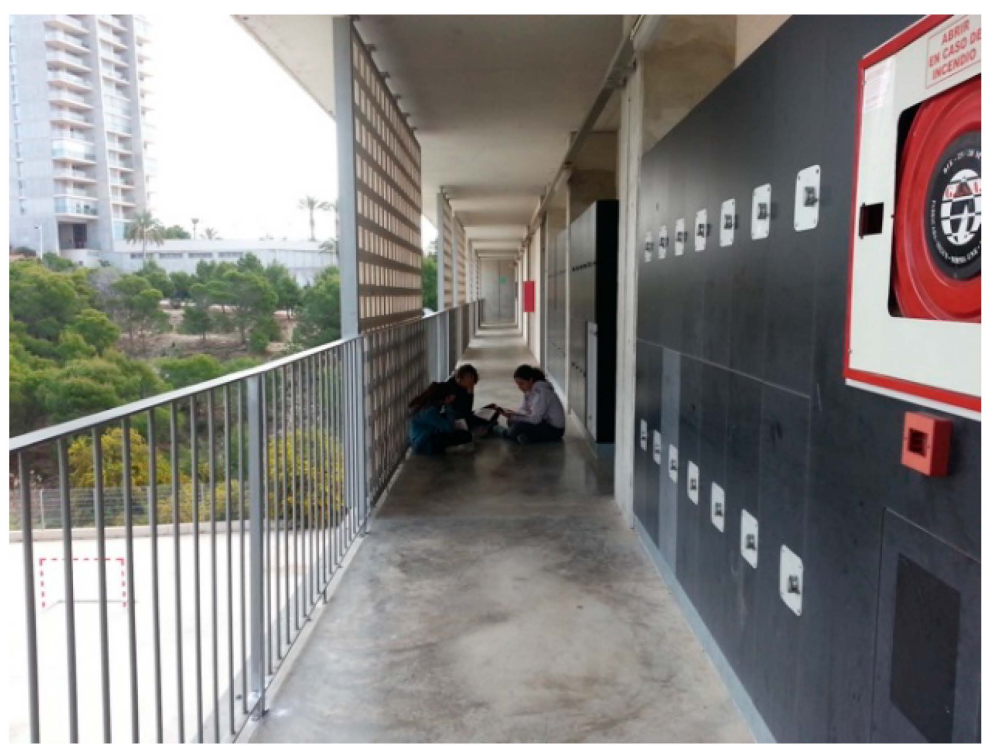

Figure 18. Group work in an open-air building. 


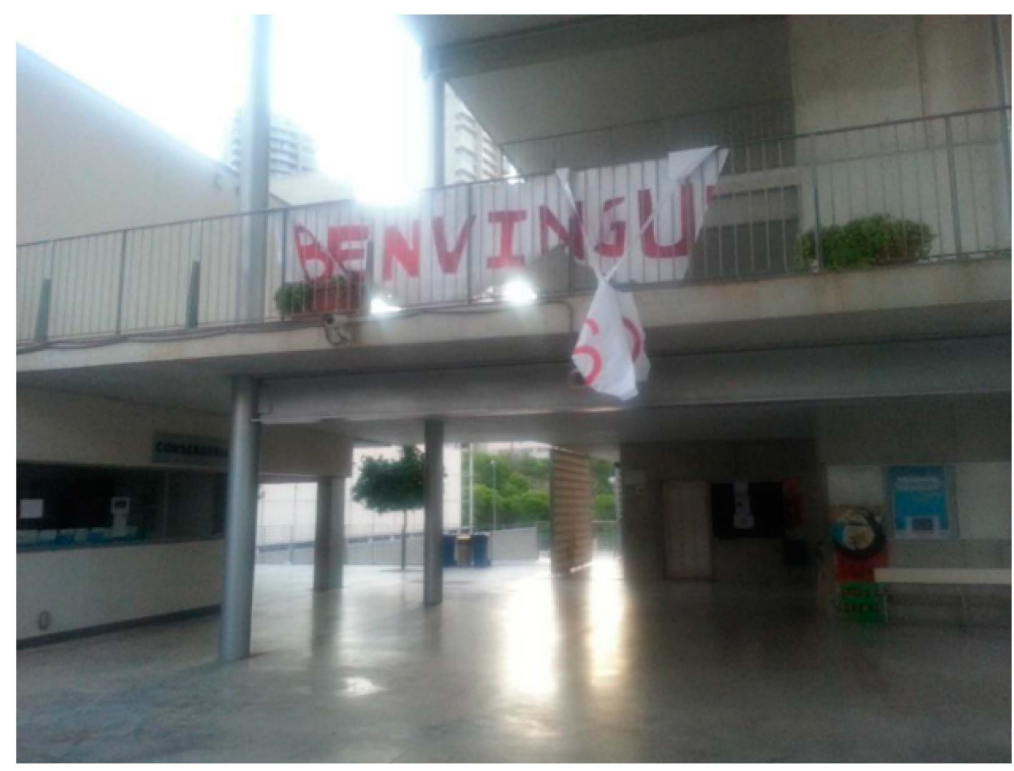

Figure 19. Entrance hall to an open-air design high school. Materials damaged by the wind.

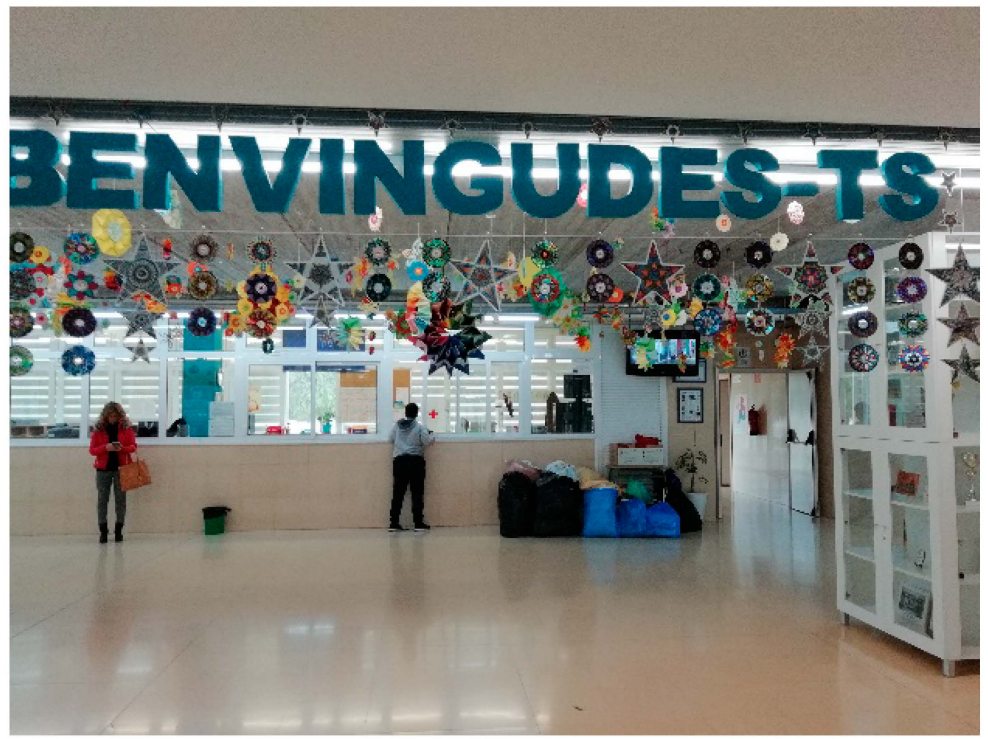

Figure 20. Indoor entrance hall decorated with students' projects.

\subsection{Recommendations}

Investment in school infrastructures improves users comfort and even has a positive effect on academic results [38]. Surely, this investment should involve an approach towards sustainability $[1,15,34]$. School buildings should be models for testing examples of sustainability development.

Principals of high schools and their teams, especially administrators, claim that very often they feel misunderstood or even isolated. In Spain, local administration is in charge of the maintenance of primary schools and so each town hall has a budget to pay for the repairs and energy consumed (electricity, gas oil). However, high schools are property of the Regional Administration (Valencia) and principals have to handle complex administrative processes to cover maintenance costs or propose changes to achieve more sustainable outcomes. Teachers and principals state that this disharmony is due to the unfamiliarity of planners and architects with the occupants needs. There is hope that new participatory design movements will contribute to shed light and generate more empathy between users, planners and policymakers [6]. 
Educational buildings should participate in the teaching-learning process as an active and dynamic element, not just as containers or receptacles that accommodate the educational community. If we assign this "teaching" role to the building, we have the responsibility to make the rooms, the walls, the ceilings, the windows, transmit the values in which we wish to educate. Sustainability is, for the authors of this paper, an essential value.

In the chart below, Table 3, we link the SDGs to our recommendations in order to move towards a greater sustainability in high school buildings.

Table 3. Recommendations towards improving sustainability in high school buildings.

\begin{tabular}{|c|c|}
\hline Sustainable Development Goal Number & Recommendations to Make Learning Spaces More Sustainable \\
\hline SDG 3. Good health and wellbeing & $\begin{array}{l}\text { - } \\
\text { - } \\
\text { Avoid designing spaces without natural ventilation. } \\
\text { - } \quad \text { Protect areas of social relation from rain or intense sunshine. } \\
\text { - } \quad \text { Enable comfortable darkening systems in order to care for visual } \\
\text { quality and eye health. } \\
\text { - } \quad \text { Use light color shutters. } \\
\text { Foster eye contact with nature in order to avoid the feeling of } \\
\text { being imprisoned. }\end{array}$ \\
\hline DG 7: Affordable and clean energy. & $\begin{array}{l}\text { - Foster and experiment the use of renewable energy in high schools } \\
\text { (photovoltaic panels and wind energy) as a model to be used in } \\
\text { other buildings. } \\
\text { - Decrease fossil fuel consumption. Establish an operating heating } \\
\text { system where certain sectors can be turned off when not needed. } \\
\text { - Construct energy efficient buildings and as far as } \\
\text { possible self-sufficient. }\end{array}$ \\
\hline $\begin{array}{l}\text { SDG 9: Industry, innovation and } \\
\text { infrastructure }\end{array}$ & $\begin{array}{l}\text { - Consider infrastructure for communication technologies and } \\
\text { - } \quad \text { Asticipate a rapid evolution. } \\
\text { - Use local resources in the construction and materials. } \\
\text { - We recommend easy to handle, standard size sun protection } \\
\text { systems which can be repaired locally and that do not block the } \\
\text { view of nature. } \\
\text { - Investigate innovation in the area of neuroscience for school } \\
\text { architecture and follow recommendations from neuroscientists for } \\
\text { improving the teaching-learning process. } \\
\text { Promote school buildings as a model of resilient and } \\
\text { sustainable infrastructures. }\end{array}$ \\
\hline SDG 11: Sustainable cities and communities. & $\begin{array}{l}\text { - } \quad \text { Increase participatory planning. } \\
\text { - } \quad \text { Implement Design Thinking workshops with stake holders. } \\
\text { - } \quad \text { Promote sustainable transport. }\end{array}$ \\
\hline $\begin{array}{l}\text { SDG 12: Responsible consumption and } \\
\text { production }\end{array}$ & $\begin{array}{l}\text { - } \quad \text { Reduce energy consumption by replacing traditional lights with } \\
\text { - } \quad \text { FED. Likewise, install presence detectors in transit areas and toilets. } \\
\text { garden initiatives. } \\
\text { - } \quad \text { Educate to limit consumption and reduce waste through activities } \\
\text { to prevent, reduce, recycle and reuse. } \\
\text { During construction or refurbishment, plan a } \\
\text { dumping/waste program. } \\
\text { Encourage companies of the public sector to adopt good practices } \\
\text { of sustainability. Architects should be aware that budgets in } \\
\text { education are always moderate and therefore we should be } \\
\text { creative to facilitate further maintenance of the building in repair } \\
\text { works, cleaning or energy consumption ("Fish tanks" require a } \\
\text { great expense in air conditioning). }\end{array}$ \\
\hline
\end{tabular}


Table 3. Cont.

\begin{tabular}{ccc}
\hline Sustainable Development Goal Number & Recommendations to Make Learning Spaces More Sustainable \\
\hline SDG 13: Climate Action & $\begin{array}{l}\text { Raise awareness about the increasing temperatures, desertification } \\
\text { and drought in SE of Spain. }\end{array}$ \\
& $\begin{array}{l}\text { Dress accordingly in order to adapt to the temperature of the space } \\
\text { and avoid an abuse of air conditioning or heating. }\end{array}$ \\
- & $\begin{array}{l}\text { We recommend natural cross-ventilation in classrooms. } \\
\text { Implement ECO-educational programs in all subjects and levels. }\end{array}$ \\
SDG 4. Quality Education & $\begin{array}{l}\text { All the foregoing redounds in an education of higher quality where } \\
\text { the building serves as a teaching element in which the students } \\
\text { gain knowledge that is not only theoretical but PRACTICAL in } \\
\text { order to promote a change in their attitudes to meet sustainable } \\
\text { development goals. }\end{array}$ \\
\hline
\end{tabular}

\section{Conclusions}

In reference to the three questions formulated for this study, we conclude the following:

1. Can the design of learning spaces provide better health and well-being for the users? The answer is affirmative. Rooms designed with little or no natural ventilation cause thermal discomfort, need air conditioning and also create smell issues. Nonetheless, when occupants work in an area exposed to drafts and rain they feel thermally uncomfortable in the opposite extreme. This in turn can lead to health problems. Teachers and students very often feel thermal discomfort if the building does not have enough indoor spaces. This fact also limits the teaching methodology and project work display and exhibitions are restricted and more expensive if they do take place.

2. Can the space design reduce maintenance costs in school buildings? A quantitative approach for this aspect has not been used and further investigation is required. However, all principals confirm that maintenance cost is increased in the following cases:

(a) When materials used and add-on elements are unique and difficult to find locally.

(b) When more electricity is required because there is overheating in some rooms and cannot be used without air conditioning or bathrooms do not have natural lighting or ventilation.

(c) When they need to turn on the central heating for the whole school, although only some rooms are occupied.

(d) When they wish to transform common use areas into different learning spaces but space flexibility has not been considered and the alteration requires a larger investment, especially if these are open-air spaces.

Is there a large gap between theory (recommendations in guides) and practice (built environment), in the studied high schools? There is a huge gap between the sustainability education that is reflected in didactic programs and building guides and the reality that most school buildings communicate. This gap is even greater in modern schools investigated in this study. More knowledge of the occupants' circumstances through participatory design (SDG 11) could facilitate the achievement of SDGs.

\section{Final Thought}

We should not cease in our efforts of sustainability, reporting things that should be changed, seeking to mirror those that work properly, in new or old building designs. Ever since the school building of IES Mediterrània started functioning, in 2006, all level of policy makers, planners and education inspectors, have been informed of the inconveniences the community suffers due to the design of the building. However, ten years later, in 2017 another high school in the province of Alicante (IES Playa Flamenca) was completed, repeating many of the same mistakes of an excessively open-air school building. The construction of the new high school in Elche should start in 2020. Hopefully, the discussions following this study will contribute to making it more sustainable and comfortable for the occupants, incorporating into our investigation a research action method in line with the Agenda 2030. 
Author Contributions: Conceptualization, I.M. and J.N.P.; Data curation, A.M.M.; Formal analysis, A.M.M.; Investigation, I.M. and A.M.M.; Methodology, J.N.P. and S.M.; Resources, G.M.D.S.; Software, G.M.D.S.; Supervision, A.M.M., J.N.P. and S.M.; Visualization, G.M.D.S.; Writing—original draft, I.M.; Writing一review \& editing, J.N.P. All authors have read and agreed to the published version of the manuscript.

Funding: This research received no external funding.

Acknowledgments: With gratitude we acknowledge the support and encouragement received from all the principals of the high schools. This study would not have been possible without their cooperation, advice and input.

Conflicts of Interest: The authors declare no conflict of interest.

\section{References}

1. Ministerio de Educación de Perú. Guía de Diseño De Espacios Educativos-Acondicionamiento De Locales Escolares Al Nuevo Modelo De Educación Básica Regular. Primaria y Secundaria; MINEDU: Lima, Perú, 2015; pp. 1-296. Available online: http://minedu.gob.pe/p/pdf/guia-ebr-jec-2015.pdf (accessed on 30 November 2019).

2. Diccionario RAE. Available online: https://dle.rae.es/sostenible?m=form (accessed on 30 November 2019).

3. Brundtland Report. Our Common Future. Available online: https://sustainabledevelopment.un.org/content/ documents/5987our-common-future.pdf (accessed on 30 November 2019).

4. Benayas, J.; Marcén, C.; Alba, D.; Gutiérrez, J. Educación Para La Sostenibilidad En España. Reflexiones Y Propuestas; OPEX: Moorestown, NJ, USA, 2017; Available online: http://reds-sdsn.es/wp-content/uploads/ 2017/10/Informe-Educacion-Sostenibilidad-2017-web.pdf (accessed on 30 November 2019).

5. Schneider, F.; Kläy, A.; Zimmermann, A.B.; Buser, T.; Ingalls, M.; Messerli, P. How can science support the 2030 Agenda for Sustainable Development? Four tasks to tackle the normative dimension of sustainability. Sustain. Sci. 2019. [CrossRef]

6. Mumovic, D.; Palmer, J.; Davies, M.; Orme, M.; Ridley, I.; Oreszczyn, T.; Way, P. Winter indoor air quality, thermal comfort and acoustic performance of newly built secondary schools in England. Build. Environ. 2009, 44, 1466-1477. [CrossRef]

7. Mora, F. Neuroeducación: Sólo Se Puede Aprender Aquello Que Se Ama; Alianza Editorial: Madrid, España, 2013.

8. Mihai, T.; Iordache, V. Determining the Indoor Environment Quality for an Educational Building. Energy Procedia 2016, 85, 566-574. [CrossRef]

9. Saraiva, T.S.; de Almeida, M.; Bragança, L.; Barbosa, M.T. Environmental comfort indicators for school buildings in sustainability assessment tools. Sustainability 2018, 10, 1849. [CrossRef]

10. García, Á.; Muñoz, J.M. Pedagogía de los espacios. Esbozo de un horizonte educativo para el siglo XXI. Rev. Española Pedagog. 2004, 228, 257-278.

11. Nair, P. Blueprint for Tomorrow: Redesigning Schools for Student-Centered Learning; Harvard Education Press: Cambridge, MA, USA, 2014.

12. López, S. Esencia. Diseño De Espacios Educativos: Aprendizaje y Creatividad; Luis Vives (Edelvives): Zaragoza, Spain, 2018; pp. 1-364.

13. Frontczak, M.; Wargocki, P. Literature survey on how different factors influence human comfort in indoor environments. Build. Environ. 2011, 46, 922-937. [CrossRef]

14. Dorizas, P.V.; Assimakopoulos, M.N.; Santamouris, M. A holistic approach for the assessment of the indoor environmental quality, student productivity, and energy consumption in primary schools. Environ. Monit. Assess. 2015, 187, 1-18. [CrossRef] [PubMed]

15. Guía de Diseño de Espacios Educativos. Proyecto Conjunto Del Ministerio De Educación Con Unesco-Orealc. In Reforma Educativa Chilena: Optimización De La Inversión En Infraestructura Educativa; MINEDUC; UNESCO: Santiago, Chile, 1999; Available online: https://unesdoc.unesco.org/ark:/48223/pf0000123168 (accessed on 30 November 2019).

16. Martínez, A.; Jordan, M.M. The relationship between indoor and outdoor levels of PM10 and its chemical composition at schools in a coastal region in Spain. Heliyon 2019. [CrossRef] 
17. Turunen, M.; Toyinbo, O.; Putus, T.; Nevalainen, A.; Shaughnessy, R.; Haverinen-Shaughnessy, U. Indoor environmental quality in school buildings, and the health and wellbeing of students. Int. J. Hyg. Environ. Health 2013, 217, 733-739. [CrossRef] [PubMed]

18. Tahsildoost, M.; Zomorodian, Z.S. Indoor environment quality assessment in classrooms: An integrated approach. J. Build. Phys. 2018, 42, 336-362. [CrossRef]

19. Wargocki, P.; Wyon, D.P. Ten questions concerning thermal and indoor air quality effects on the performance of office work and schoolwork. Build. Environ. 2017, 112, 359-366. [CrossRef]

20. Ré, M.G.; Filippin, C.; Blasco Lucas, I. Niveles De Confort Térmico En Aulas De Dos Edificios Escolares Del Área Metropolitana De San Juan. Av. En Energías Renov. Y Medio Ambiente 2017, 5, 97-108.

21. Toyinbo, O.; Shaughnessy, R.; Turunen, M.; Putus, T.; Metsämuuronen, J.; Kurnitski, J.; Haverinen-Shaughnessy, U. Building characteristics, indoor environmental quality, and mathematics achievement in Finnish elementary schools. Build. Environ. 2016, 104, 114-121. [CrossRef]

22. Michael, A.; Heracleous, C. Assessment of natural lighting performance and visual comfort of educational architecture in Southern Europe: The case of typical educational school premises in Cyprus. Energy Build. 2017, 140, 443-457. [CrossRef]

23. Carlucci, S.; Causone, F.; De Rosa, F.; Pagliano, L. A review of indices for assessing visual comfort with a view to their use in optimization processes to support building integrated design. Renew. Sustain. Energy Rev. 2015, 47, 1016-1033. [CrossRef]

24. Climatic Data. Available online: http://agroclimap.aemet.es/\# (accessed on 30 November 2019).

25. Historical Climatic Data in Elche. Available online: https://es.climate-data.org/europe/espana/comunidadvalenciana/elche-1999/ (accessed on 3 February 2020).

26. Agencia Estatal Boletín Oficial del Estado 1997 REAL DECRETO 485/1997 De 14 De Abril, Sobre Disposiciones Mínimas En Materia De Señalización De Seguridad Y Salud En El Trabajo. Available online: https: //www.boe.es/buscar/pdf/1997/BOE-A-1997-8668-consolidado.pdf (accessed on 6 February 2020).

27. School Calendar Year 19/20. Available online: http://www.dogv.gva.es/datos/2019/06/13/pdf/2019_6051.pdf (accessed on 6 February 2020).

28. Elche Local News. Available online: https:/teleelx.es/2019/09/11/suspenden-las-clases-en-elche-para-estejueves-ante-el-riesgo-de-gota-fria/ (accessed on 6 February 2020).

29. Agencia Estatal Boletín Oficial Del Estado 1990. Ley Orgánica 1/1990, De 3 De Octubre, De Ordenación General Del Sistema Educativo. Available online: https://www.boe.es/eli/es/lo/1990/10/03/1 (accessed on 30 November 2019).

30. Agencia Estatal Boletín Oficial Del Estado 2010 REAL DECRETO 132/210 De 12 De Febrero, Por El Que Se Establecen Los Requisitos Mínimos De Los Centros Que Impartan Las Enseñanzas Del Segundo Ciclo De La Educación Infantil, La Educación Primaria Y La Educación Secundaria. Available online: https://www.boe.es/buscar/doc.php?id=BOE-A-2010-4132 (accessed on 30 November 2019).

31. Elche Local Media. Available online: https://alicanteplaza.es/el-ies-vicente-verdu-llegara-a-elche-diez-anosdespues-la-primera-gran-obra-del-edificant (accessed on 6 February 2020).

32. Montiel, I.; Mayoral, A.M.; Navarro Pedreño, J.; Maiques, S. Acoustic Comfort in Learning Spaces: Moving Towards Sustainable Development Goals. Sustainability 2019, 11, 3573. [CrossRef]

33. Agencia Estatal Boletín Oficial Del Estado 2019 REAL DECRETO 244/2019, De 5 De Abril, Por El Que Se Regulan Las Condiciones Administrativas, Técnicas Y Económicas Del Autoconsumo De Energía Eléctrica. Available online: https://www.boe.es/boe/dias/2019/04/06/pdfs/BOE-A-2019-5089.pdf (accessed on 30 November 2019).

34. Instrucciones De Diseño Actualizadas 2019. Available online: http://www.ceice.gva.es/documents/161863110/ 168577118/Instrucciones+de+dise \%C3\%B1o+y+construcci $\% C 3 \%$ B3n+para+edificios+de+uso+docente. +Renovadas+19/7d4ebd0e-db89-49ea-8901-fc48f4b2da1e (accessed on 30 November 2019).

35. Rantala, L.; Sala, E. Associations between classroom conditions and teacher's voice production. Energy Procedia 2015, 8, 3120-3125. [CrossRef]

36. Ubillos, S.; Centeno, J.; Iba, J. Protective and Risk Factors Associated With Voice Strain Among Teachers in Castile and Leon, Spain: Recommendations for Voice Training: Factores de Riesgo y Protección de los Tratamientos Foniátricos en Docentes de Castilla y León: Pautas para la Formación Vocal. J. Voice 2015, 29, 1-12. [CrossRef] 
37. Byers, T.; Imms, W.; Hartnell-Young, E. Evaluating teacher and student spatial transition from a traditional classroom to an innovative learning environment. Stud. Educ. Eval. 2018, 58, 156-166. [CrossRef]

38. Crampton, F.E. Spending on school infrastructure: Does money matter? J. Educ. Adm. 2009, 47, $305-322$. [CrossRef]

(C) 2020 by the authors. Licensee MDPI, Basel, Switzerland. This article is an open access article distributed under the terms and conditions of the Creative Commons Attribution (CC BY) license (http://creativecommons.org/licenses/by/4.0/). 